Published in final edited form as:

Curr Opin Ophthalmol. 2018 May ; 29(3): 267-274. doi:10.1097/ICU.0000000000000466.

\title{
Cytokines in uveitis
}

\author{
Jessica E. Weinstein, Kathryn L. Pepple \\ University of Washington, Department of Ophthalmology, Seattle, Washington, USA
}

\begin{abstract}
Purpose of review-Increasing evidence supports Th17 cells as key mediators of ocular inflammatory disease. Cytokines that are important for the development and pathologic function of these cells are potential therapeutic targets in patients with immune mediated uveitis. This review provides an overview of these cytokines including recent insights about their roles in ocular inflammation from laboratory and clinical studies.
\end{abstract}

Recent findings-Interleukin (IL)-6, IL-10, IL-17, IL-22, IL-23 and tumour necrosis factoralpha (TNFa) are cytokines that have been examined for their functional role in uveitis and their relationship to pathologic Th17 cells. Studies in animal models, particularly in experimental autoimmune uveitis (EAU), have been instrumental in studying the role of these cytokines in disease pathogenesis. More recently, studies on aqueous, vitreous and serum from patients with uveitis using flow cytometry and multiplex ELISA bead-based methodologies have provided insights into the contribution of Th17 cells and the related cytokines in ocular inflammatory diseases. The central role of IL-23 in determining the pathologic Th17 fate has made it an effective therapeutic target in systemic diseases such as psoriasis and thereby an attractive potential target for patients with immune-mediated uveitis.

Summary-Th17 cells, and their related cytokines, are important inflammatory mediators in autoimmune uveitis. Animal and human studies continue to provide new information to direct development of new cytokine-targeted therapies for patients with uveitis.

\section{Keywords}

cytokines; interleukin -6; interleukin-10; interleukin-17; interleukin-22; interleukin-23; tumour necrosis factor-alpha; uveitis

\section{INTRODUCTION}

$\mathrm{T}$ cells expressing the surface marker cluster of differentiation 4 (CD4) are known as $\mathrm{T}$ helper (Th) cells and play important roles in the pathogenesis of autoimmune diseases including uveitis. Th cells can be classified into different functional categories by the small molecule cytokines they secrete, as well as by the transcription factors required for their development. After the initial discovery of Th cells and their importance in adaptive

Correspondence to Kathryn L. Pepple, University of Washington, Seattle, WA, 98104, USA. Tel: +1 206616 1292; fax: +1 206685 7055; kpepple@uw.edu.

Conflicts of interest

There are no conflicts of interest. 
immunity, two major classes of Th cells were defined in a paradigm that shaped the approach to autoimmunity for the next two decades [1]. In this paradigm, Th1 cells, defined by the expression of the transcription factor T-bet and secretion of interferon gamma (IFN $\gamma$ ), were the dominant cell type 'helping' cellular immunity, while Th2 cells, defined by the transcription factor GATA binding protein 3 and secretion of interleukin (IL)-4 and IL-5, were responsible for helping humoral immunity [2]. This original paradigm maintained that additional populations of helper cells were likely to be discovered to fill additional immunemodulating roles. This prediction has subsequently been realized with the identification of regulatory T cells (Tregs) and Th17 cells, among others (Th22, Th9, Th3, Follicular helper $\mathrm{T}_{\mathrm{FH}}$ ). Treg cells are important in maintaining tolerance and preventing autoimmunity and can be identified by their expression of the forkhead box P3 (Foxp3) transcription factor and their ability to produce transforming growth factor beta (TGF $\beta$ ), IL-10 and IL-35 [3]. In addition to their role in autoimmunity, Th17 cells are important in maintaining normal mucosal health and immunity, and can be identified by their expression of the transcription factor RAR-related orphan receptor gamma (ROR $\gamma \tau$ ) and expression of IL-17, IL-21, IL-22 and tumour necrosis factor-alpha (TNFa) [4].

The mechanisms of uveitis development and maintenance were initially attributed to a Th1dominated response, but when IFN $\gamma$ deficiency was not sufficient to suppress the development of experimental autoimmune uveitis (EAU), the roles ofTh17 cells and IL-17 in uveitis were identified [5,6]. In animal models, the interplay between the Th1 and Th17 responses in driving uveitis is complex, as both can drive intraocular inflammation given the correct context [5,7]. Furthermore, Th17 cells that also express IFN $\gamma$ have been identified in human uveitis $\left[8^{\mathbf{H}}\right.$ ] as well as other inflammatory diseases [9], suggesting that there may be overlap and plasticity between Th subtypes.

Th17 cells develop from naive CD4 ${ }^{+}$T cells in the presence of IL- $1 \beta$, IL- 6 and TGF $\beta$ produced by antigen-presenting cells (APCs). IL-23 has a distinct role in the development of autoimmunity, as in the absence of IL-23, Th17 cells still develop, but they are not pathogenic and perform essential homeostatic functions [10]. In addition to IL-17, Th17 cells express IL-22, IL-17F, IL-21, granulocyte macrophage colony-stimulating factor (GMCSF), IL-6 and IFN $\gamma$, which all have important inflammatory functions in autoimmunity [4].

\section{INTERLEUKIN-17}

IL-17 is part of the IL-17 family of cytokines. This family includes IL-17 (also known as IL-17A), IL-17B, IL-17C, IL-17D, IL-25and IL-17F. IL-17receptor (IL-17R) signalling uses an adaptor system that is distinct from other interleukin receptor families to activate downstream regulators of the inflammatory response such as nuclear factor kappa beta (NFkB) and c-Jun N-terminal kinases (JNK) [11]. Instead of utilizing the receptor tethered kinases of the janus kinase and signal transducer and activator of transcription (JAK-STAT) system, IL-17R family members contain an intracellular SEF/IL-17R (SEFIR) domain that provides a docking site for the Act1 adaptor protein, which activates tumour necrosis receptor associated factor 6 (TRAF6) through poly-ubiquitination [12]. In addition to driving inflammatory cytokine expression, IL-17 signalling also drives the expression of 
metalloproteases that can cause tissue injury and of chemokines that recruit neutrophils to the site of inflammation. IL-17 is secreted by Th17 cells as well as natural killer (NK) cells, gamma delta $(\gamma \delta) \mathrm{T}$ cells and a subset of CD8 T cells called Tc17 cells.

\section{Roles in uveitis}

In EAU, both Th17 cells and IL-17 appear to have an important role in driving inflammation. In the adoptive transfer model of EAU, interphotoreceptor retinoid binding protein (IRBP) specific Th17 cells are sufficient to induce uveitis [13], and treatment with anti-IL-17 antibody is sufficient to block development of disease [14]. However, while Th17 cells and IL-17 were initially identified for their pro-inflammatory roles in uveitis, roles in immune regulation have also been reported. For example, IL-10 expressing, nonpathogenic Th17 cells with the ability to prevent EAU have been identified in mouse models at higher density than retina-specific pathogenic Th17 cells [15]. In addition, recombinant human IL-17 given systemically in the chronic relapsing EAU rat model paradoxically protected against inflammation [16].

In humans, elevated levels of IL-17 were identified in the eyes of patients with birdshot chorioretinopathy (BSCR) [17], Vogt-Koyanagi-Harada (VKH), as well as in HLA-B27 and Behcet's uveitis [18]. Elevated serum levels of IL-17A have also been identified in patients with immune-mediated uveitis [19], and in association with active disease in patients with Behcet's uveitis [20].

\section{Anti-interleukin-17 therapy options and results of treatment in uveitis}

Secukimumab (Consentyx, Novartis, Basel, Switzerland) is a Food and Drug Administration (FDA)-approved human antibody directed against IL-17A for the treatment of psoriasis [21,22], psoriatic arthritis [23,24] and ankylosing spondylitis [25]. Phase III dose-dependent studies for secukimumab in uveitis (INSURE, ENDURE and SHIELD) failed to demonstrate efficacy and the studies were terminated early [26]. These results were surprising, but the complex roles IL-17 plays in health and disease, and the route of drug delivery could have contributed to these findings. In the study by Letko et al. [27], patients with uveitis were treated with either intravenous or subcutaneous secukinumab. This trial found that patients treated via the intravenous route had a higher rate of improvement in vitreous haze score and in achieving disease remission [27]. The authors concluded that the subcutaneous route might not produce clinically effective drug levels. Due to the fact that the INSURE,

ENDURE and SHIELD trials all used subcutaneous administration, this could have played a role in the failure of these trials to demonstrate efficacy. Other available anti-IL-17 therapies include ixekizumab (Taltz, Eli Lilly, Indianapolis, Indiana, USA), approved for moderate to severe plaque psoriasis [28] and active psoriatic arthritis [29 ,30], and brodalumab (Sidiq, Valeant, Laval, Quebec, Canada), which is approved for moderate to severe plaque psoriasis [31-33]. To date, no reports of these agents in patients with uveitis have been published.

\section{INTERLEUKIN-23}

IL-23 is a member of the IL-12 superfamily of cytokines. This family includes

IL-12,IL-23,IL-27 and IL-35. IL-23 is a heterodimeric protein composed of the p19 subunit,

Curr Opin Ophthalmol. Author manuscript; available in PMC 2020 May 05. 
which is unique to IL-23, and the p40 subunit that is shared with IL-12. The IL-23 receptor is composed of the IL-12Rb1 and unique IL-23R subunits that signal through tyrosine kinase 2 (Tyk2), JAK2, STAT3 and STAT4 upon binding IL-23 [34]. IL-23 functions as a crucial checkpoint governing the development of pathologic Th17 cells [35,36]. In the absence of IL-23, Th17 cells can still develop, but do not become pathogenic. In the context of inflammation, IL-23 is primarily produced by antigen-presenting cells such as dendritic cells and macrophages. Inflammatory cells that express the IL-23R include $\mathrm{CD} 4^{+}$and $\mathrm{CD} 8^{+} \mathrm{T}$ cells, $\gamma \delta \mathrm{T}$ cells, group 3 innate lymphoid cells and invariant NK cell [37].

\section{Roles in uveitis}

Mice deficient in either IL-23p19 or IL-12p40 subunits exhibit protection from developing EAU [5]. In humans, elevated serum levels of IL-23 have been identified in patients with VKH [38] and BSCR [39]. Elevated serum IL-23 has also been identified as a risk factor for developing uveitis in spondyloarthropathy patients [40]. The data from intraocular studies are mixed. One study analysing aqueous sample did not detect elevated IL-23 in patients with VKH, Behcet"s, idiopathic, HLA-B27 or sarcoid uveitis [41]. On the contrary, a proteomic study of vitreous samples from patients with posterior uveitis identified increased IL-23 [42]. Single nucleotide polymorphisms in the $I L-23 R$ gene have also been associated with an increased risk of inflammatory disease, including ankylosing spondylitis associated uveitis, Behcet's disease, VKH and sarcoid uveitis [43-45].

\section{Anti-interleukin-23 therapy options and studies in patients with uveitis}

Ustekinumab (Stelara, Janssen, Beerse, Belgium) is a mAb directed against the IL-12p40 subunit of both IL-23 and IL-12. It is FDA approved for the treatment of moderate to severe Crohn's disease [46,47], moderate to severe plaque psoriasis [48-50] and active psoriatic arthritis [51,52]. It is currently being studied in two phase II clinical trials for the treatment of patient with uveitis; STELARA (NEI, NCT02911116) and STELABEC (Assistance publique - Hôpitaux de Paris, NCT02648581). Guselkumab (Tremfya, Janssen, Beerse, Belgium) and tildrakizumab (Sun Pharmaceuticals, Mumbai, Maharashtra, India) are mAbs that target the IL-23specificp19subunit. Both drugs have FDA approval for use in moderate to severe plaque psoriasis [53-56]. Other p19 specific agents include brazikumab (Amgen, Thousand Oaks, California, USA), which is in development for Crohn's disease [57], and risankizumab (Abbvie, North Chicago, Illinois, USA) in development for psoriasis [58], Crohn's disease [59], psoriatic arthritis (Abbvie, NCT02986373).

\section{INTERLEUKIN-6}

IL-6 is a well known and important mediator of autoimmune diseases including uveitis [60]. It belongs to a family of cytokines including IL-11, IL-31, ciliary neurotrophic factor (CNTF), Cardiotrophin-1 (CT-1), leukaemia inhibitory factor (LIF), osteopenia (OPN) and oncostatin M (OSM). IL-6 functions by binding either a cell surface (IL-6R) or a soluble IL-6 receptor (sIL-6R). The IL-6R consists of the IL-6Ra chain (CD-126) and a signal transducing component called gp130. Gp130 is a ubiquitous signal transducer used by all members of the IL-6-like cytokine family. The IL-6/sIL6-R complex can bind any cell expressing gp130 allowing a wide variety of cell types to respond to IL-6 [60]. The binding

Curr Opin Ophthalmol. Author manuscript; available in PMC 2020 May 05. 
of IL-6 to its receptor results in the activation of the JAK-STAT (JAK1, JAK2, STAT3) and mitogen-activated protein kinase (MAPK) pathways, ultimately leading to the expression of inflammatory cytokines, vascular endothelial growth factor (VEGF) and differentiation of naive $\mathrm{CD}^{+} \mathrm{T}$ cells into Th17 cells [61]. Activation of STAT3 also induces the suppressor of cytokine signalling 1 (SOCS1) and SOCS3, which are negative inhibitors of IL-6 signalling $[62,63]$.

\section{Roles in uveitis}

In experimental studies, EAU is significantly attenuated in IL-6 deficient animals [64], and intravitreal anti-IL-6 reduces inflammation [65 ]. In humans, elevated levels of IL-6 have been detectedin the aqueous humour of Behcet's disease, VKH, sarcoid, idiopathic uveitis, acute retinal necrosis and HLA-B27 mediated uveitis when compared with controls [41,66,67]. IL-6 also plays a role in uveitis complications such as neovascularization and macular oedema [68-70].

\section{Anti-interleukin-6 therapy options and results of treatment in uveitis}

Tociluzimab (Actemra, Genentech, South San Francisco, California, USA) was the first FDA-approved anti-IL-6 agent. It is a humanized mAb against the membrane bound IL-6R and the soluble sIL-6R and is currently approved for the treatment of rheumatoid arthritis (RA) [71], and juvenile idiopathic arthritis[72].Currently, it remains an off-label agent for use in uveitis, but the efficacy and safety of tocilizumab in noninfectious uveitis is being investigated in the on-going STOP-UVEITIS trial (University of Nebraska, NCT01717170). The early 6-month results for this study showed improvement of vision, in vitreous haze and reduction in macular central mean thickness with the use of tocilizumab [73 ${ }^{\mathbf{H}}$ ]. Used in an off-label small case series, tocilizumab was reported to be successful in treating refractory noninfectious uveitis that has been unresponsive to TNF inhibitors [74] and to treat refractory uveitic macular oedema [75].

Sarilumab (Kevzara, Regeneron, Tarrytown, New York, USA) is another humanized mAb against the IL-6R that received FDA approval for treatment of RA in 2017 [76,77]. As an alternative to targeting the receptor, other anti-IL6 agents target the cytokine itself. Siltuximab (Sylvant, Janssen, Beerse, Belgium) is a chimeric mAb with FDA approval for treatment of multicentric Castleman's disease [78]. Olokizumab (UCB group, Brussels, Belgium) and sirukumab (Janssen, Beerse, Belgium) are humanized mAbs in development for treatment of RA, while clazakizumab (Alder, Bothell, Washington, USA) is a humanized rabbit $\mathrm{mAb}$ in development for psoriatic arthritis [79]. None of these therapies have been tested in patients with uveitis, so the full potential of anti-IL-6 therapy for ocular disease has yet to be discovered.

\section{TUMOUR NECROSIS FACTOR ALPHA}

$\mathrm{TNFa}$ is a member of the tumour necrosis factor family, which includes TNFa, lymphotoxin, B-cell activating factor (BAFF) and a proliferation inducing ligand (APRIL). TNFa has both a membrane bound form and a soluble form. TNF Receptor 1 (TNFR-1) is the main receptor for either form and it is ubiquitously expressed on all cells. TNFR-2 is 
only expressed on immune cells and only responds to membrane bound TNFa. Soluble versions of these receptors exist and act as an inhibitor to TNFa and is the mechanism by which etanercept (Enbrel, Amgen/Pfizer) functions therapeutically. Binding of TNFa to its receptor elicits a complex signalling cascade that is mediated through TNF receptor associated factor (TRAF) proteins [80]. Events downstream of TRAF include translocation of NF- $\kappa \mathrm{B}$ to the nucleus for production of pro-inflammatory cytokines and activation of the MAPK cascade. TNFa is produced by all immune cells; however, NK cells, activated macrophages, activated T cells, mast cells and endothelial cells produce them predominantly when there is an inflammatory stimulus.

\section{Roles in uveitis}

In the EAU model, neutralization of TNFa suppresses disease [81] and mice deficient in TNFR1 are resistant to the development of uveitis [82]. In humans, aqueous sampling has identified elevated TNFa levels in patients with HLA-B27, idiopathic uveitis, VKH and Behcet's uveitis $[18,66]$. However, aqueous levels do not appear to reflect the impact of disease activity or treatment with systemic adalimumab [83]. In one patient cohort with intermediate uveitis, aqueous levels of TNFa were similar to controls; however, serum TNFa was elevated [70].

\section{Anti-tumour necrosis factor-alpha therapy options and results of treatment in uveitis}

TNFa inhibitors were initially approved for treatment of patients with RA. Off-label use in patients with uveitis identified evidence of efficacy, which lead to recommendations for their use prior to FDA approval [84]. The landmark VISUAL 1 and 2 trials subsequently led to the approval of adalimumab (Humira, Abbvie, North Chicago, Illinois, USA) for treatment of patients with noninfectious uveitis in 2016 [85,86]. Infliximab (Remicade, Janssen, Beerse, Belgium) is a chimeric mAb that has been used off label as an effective treatment for patients with uveitis [84]. Golimumab (Simponi Aria, Janssen, Beerse, Belgium) is another human $\mathrm{mAb}$ approved for treatment of psoriatic and RA, ankylosing spondylitis and ulcerative colitis. Several retrospective case studies have reported successful use of golimumab in patients with uveitis, but no larger controlled trials have been performed $[87,88,89]$. Etanercept was the first clinically available anti-TNF agent. In contrast to other medications in this class that target the TNFa molecule itself, etanercept is a fusion protein of the TNF receptor with a human Fc molecule. Etanercept is approved for use in the treatment of several rheumatologic conditions but has not demonstrated effectiveness in patients with uveitis [90]. In addition, there is a concern that etanercept may induce ocular inflammation in certain patients, so it is not recommended for the treatment of those with a known history of uveitis [91,92].

\section{INTERLEUKIN-22}

IL-22 is a member of the IL-10 family and acts primarily on nonlymphoid tissue to potentiate inflammation in association with IL-17, TNFa and IL-1 $\beta$ signalling. However, IL-22 also has essential homeostatic and immunoregulatory functions, particularly at barrier surfaces $[93,94]$. T cells and innate lymphoid cells (ILCs) are the main sources of IL-22, but other cells such as NK T (NKT) cells, $\gamma \delta \mathrm{T}$ cells and CD8 T cells can also produce IL-22, 
particularly in the presence of IL-23 [95]. Although IL-22 can be expressed by both Th1 and Th17 cells, there is also an IL-22 specific Th subset known as Th22 cells [96 ${ }^{\mathbf{W}}$ ]. The IL-22 receptor (IL-22R) is a type 2 cytokine receptor composed of two heterodimeric subunits, IL-22Ra and IL-10Rb. Upon binding its receptor, downstream signalling is activated through the JAK-STAT pathway (JAK1, Tyk2 and primarily STAT3). Other pathways involved in IL-22 signal transduction include the MAPK, phosphoinositide 3-kinase (PI3K), AKT and mammalian target of rapamycin (mTOR) pathways [97].

\section{Roles in uveitis}

In EAU, while IL-22 is produced by pathogenic Th cells, small doses of IL-22 led to a reduced severity of uveitis mediated by myeloid (CD11b+) cells [98], and IL-22 deficient animals developed worse inflammation than controls [99]. In humans, IL-22 producing Th clones have been isolated from the eyes and peripheral blood of patients with Behcet's disease [100], and elevated levels of serum IL-22 have been identified in patients with uveitis [101] and scleritis [102]. In addition, IL-22 serum levels decreased in response to treatment with adalimumab and this correlated with the disease activity [103]. Genetic studies have also identified an increase in IL-22 gene expression in patients with noninfectious uveitis [104]. Taken together, the human and animal studies suggest that IL-22, like its family member IL-10, may primarily have immune regulatory rather than inflammatory functions in the eye.

\section{Interleukin-22 therapy options and results of treatment in uveitis}

Fezakinumab (Pfizer, New York, New York, USA) is a human mAb against IL-22 that was tested in a phase I trial for psoriasis (Wyeth/Pfizer, NCT00563524) and a phase II trial for RA (Pfizer, NCT00883896). The results of these studies were not published, and commercial development has not ensued. Results from an additional phase II trial in patients with moderate to severe atopic dermatitis (Rockefeller University, NCT01941537) are anticipated in 2018. No studies are being conducted in patients with uveitis.

\section{INTERLEUKIN-10}

IL-10 is the founding member of the IL-10 cytokine superfamily, which also includes IL-19, IL-20, IL-22, IL-24,IL-26, IL-28 and IL-29 [105]. IL-10 was identified by its ability to inhibit IFN $\gamma$ from Th1 cells [106], and it continues to be one of the more important immunoregulatory cytokines, controlling and moderating inflammatory responses [107]. It is secreted by activated T cells, macrophages, dendritic cells, NK cells and B-cells [108]. The IL-10 receptor (IL-10R) is a tetramer consisting of two $\alpha$ and two $\beta$ subunits, where $\alpha$ are responsible for binding IL-10 and $\beta$ is part of signal transduction. Like many other cytokines, receptor signalling is mediated by the JAK-STAT pathway, in this case through JAK1, STAT1and STAT3 [109]. Binding of IL-10 to its receptor leads to suppression of inflammatory cytokine gene transcription, inhibition of macrophage activation, downregulation of major histocompatability complex class II expression on APCs and antiapoptotic activity.

Curr Opin Ophthalmol. Author manuscript; available in PMC 2020 May 05. 


\section{Roles in uveitis}

Animal studies demonstrate the protective role of local IL-10 in uveitis, both in EAU and endotoxin-induced uveitis (EIU) [110-114]. In patients with uveitis, elevated intraocular IL-10 levels have been identified [70,115,116], and are attributed to the presence of regulatory mechanisms activated in tandem with inflammation. In the majority of these reports, the ratio of IL-10 to IL-6 was lower than 1. In cases wherein an elevated ratio of IL-10 to IL-6 (greater than 1) is identified, it is strongly suggestive of the presence of primary intraocular lymphoma $\left[17^{\mathbf{W}}, 118^{\mathbf{}}, 119,120\right]$.

\section{Interleukin-10 therapy options and studies of treatment in uveitis}

Recombinant human IL-10 was tested as a potential therapy for patients with ulcerative colitis in several large multicentre trials [121-123]. Although it was found to be a well tolerated medication, it was no more effective than placebo. Around $40 \%$ of the patients in the trial also had extraintestinal manifestations of ulcerative colitis including uveitis, but no separate subanalysis was performed to determine an effect of IL-10 on these manifestations. Local administration has been suggested as a possible means to overcome treatment failure in ulcerative colitis [124], and on the basis of data from EAU and EIU, this may be an option to explore for patients with uveitis [111]

\section{CONCLUSION}

The Th17 cell subtype is critical to the pathogenesis of autoimmune uveitis. Cytokines associated with the differentiation, regulation and effector functions of these cells are the cytokines IL-6, IL-10, IL-17, IL-22, IL-23 and TNFa. This association has made them attractive candidates for therapeutic targeting in inflammatory diseases including ocular inflammation. Although a TNFa inhibitor is the only FDA-approved biologic therapy to treat uveitis, agents targeting IL- 6 and IL-23 are being evaluated in clinical trials and have the potential to provide benefit.

\section{Acknowledgments}

Financial support and sponsorship

This work was supported by a Research to Prevent Blindness career development award (K.L.P.) and unrestricted departmental grant, the National Institute of Health and the National Eye Institute, NEI K08EY023998 (K.L.P.), and the Cynthia and Joseph Gensheimer Fellowship (J.E.W.).

\section{REFERENCES AND RECOMMENDED READING}

Papers of particular interest, published within the annual period of review, have been highlighted as:

- of special interest

U of outstanding interest

1. Mosmann TR, Cherwinski H, Bond MW, et al. Two types of murine helper T cell clone. I. Definition according to profiles of lymphokine activities and secreted proteins. J Immunol 1986; 136:2348-2357. [PubMed: 2419430] 
2. Mosmann TR, Coffman RL. TH1 and TH2 cells: different patterns of lymphokine secretion lead to different functional properties. Annu Rev Immunol 1989; 7:145-173. [PubMed: 2523712]

3. Li X, Zheng Y. Regulatory T cell identity: formation and maintenance. Trends Immunol 2015; 36:344-353. [PubMed: 25981968]

4. Korn T, Bettelli E, Oukka M, Kuchroo VK. IL-17 and Th17 cells. Annu Rev Immunol 2009; 27:485-517. [PubMed: 19132915]

5. Luger D, Silver PB, Tang J, et al. Either a Th17 or a Th1 effector response can drive autoimmunity: conditions of disease induction affect dominant effector category. J Exp Med 2008; 205:799-810. [PubMed: 18391061]

6. Jones LS, Rizzo LV, Agarwal RK, et al. IFN-gamma-deficient mice develop experimental autoimmune uveitis in the context of a deviant effector response. J Immunol 1997; 158:5997-6005. [PubMed: 9190954]

7. Caspi RR. Understanding autoimmunity in the eye: from animal models to novel therapies. Discov Med 2014; 17:155-162. [PubMed: 24641958]

8. Zhuang Z, Wang Y, Zhu G, et al. Imbalance of Th17/Treg cells in pathogenesis of patients with human leukocyte antigen B27 associated acute anterior uveitis. Sci Rep 2017; 7:40414. [PubMed: 28091550] This study looked at levels of Th17 and Treg cells in the peripheral blood of patients with HLA-B27 associated uveitis. They observed an increase in Th17 cells that positively correlated with disease activity, and a decrease in Treg cells that negatively correlated with disease activity.

9. Hirota K, Duarte JH, Veldhoen M, et al. Fate mapping of IL-17-producing T cells in inflammatory responses. Nat Immunol 2011; 12:255-263. [PubMed: 21278737]

10. Gaffen SL, Jain R, Garg AV, Cua DJ. The IL-23-IL-17 immune axis: from mechanisms to therapeutic testing. Nat Rev Immunol 2014; 14:585-600. [PubMed: 25145755]

11. Song X, Qian Y. The activation and regulation of IL-17 receptor mediated signaling. Cytokine 2013; 62:175-182. [PubMed: 23557798]

12. Zhang B, Liu C, Qian W, et al. Structure of the unique SEFIR domain from human interleukin 17 receptor A reveals a composite ligand-binding site containing a conserved a-helix for Act1 binding and IL-17 signaling. Acta Crystallogr D Biol Crystallogr 2014; 70:1476-1483. [PubMed: 24816115]

13. Peng Y, Han G, Shao H, et al. Characterization of IL-17+ interphotoreceptor retinoid-binding protein-specific T cells in experimental autoimmune uveitis. Invest Ophthalmol Vis Sci 2007; 48:4153-4161. [PubMed: 17724201]

14. Zhang R, Qian J, Guo J, et al. Suppression of experimental autoimmune uveoretinitis by anti-IL-17 antibody. Curr Eye Res 2009; 34:297-303. [PubMed: 19373578]

15. Nian H, Liang D, Zuo A, et al. Characterization of autoreactive and bystander IL-17+ T cells induced in immunized C57BL/6 mice. Invest Ophthalmol Vis Sci 2012; 53:897-905. [PubMed: 22247477]

16. Ke Y, Liu K, Huang GQ, et al. Anti-inflammatory role of IL-17 in experimental autoimmune uveitis. J Immunol 2009; 182:3183-3190. [PubMed: 19234216]

17. Kuiper JJ, Mutis T, de Jager W, et al. Intraocular interleukin-17 and pro-inflammatory cytokines in HLA-A29-associated birdshot chorioretinopathy. Am J Ophthalmol 2011; 152:177-182; e171. [PubMed: 21570674]

18. El-Asrar AM, Struyf S, Kangave D, et al. Cytokine profiles in aqueous humor of patients with different clinical entities of endogenous uveitis. Clin Immunol 2011; 139:177-184. [PubMed: 21334264]

19. Jawad S, Liu B, Agron E, et al. Elevated serum levels of interleukin-17A in uveitis patients. Ocul Immunol Inflamm 2013; 21:434-439. [PubMed: 23957503]

20. Na SY, Park MJ, Park S, Lee ES. Up-regulation of Th17 and related cytokines in Behcet's disease corresponding to disease activity. Clin Exp Rheumatol 2013; 31:32-40. [PubMed: 24064012]

21. Langley RG, Elewski BE, Lebwohl M, et al. Secukinumab in plaque psoriasis: results of two phase 3 trials. N Engl J Med 2014; 371:326-338. [PubMed: 25007392]

22. Blauvelt A, Prinz JC, Gottlieb AB, et al. Secukinumab administration by prefilled syringe: efficacy, safety and usability results from a randomized controlled trial in psoriasis (FEATURE). Br J Dermatol 2015; 172:484-493. [PubMed: 25132411] 
23. McInnes IB, Mease PJ, Kirkham B, et al. Secukinumab, a human antiinterleukin-17A monoclonal antibody, in patients with psoriatic arthritis (FUTURE 2): a randomised, double-blind, placebocontrolled, phase 3 trial. Lancet 2015; 386:1137-1146. [PubMed: 26135703]

24. Mease PJ, McInnes IB, Kirkham B, et al. Secukinumab inhibition of interleukin-17A in patients with psoriatic arthritis. N Engl J Med 2015; 373:1329-1339. [PubMed: 26422723]

25. Baeten D, Sieper J, Braun J, et al. Secukinumab, an interleukin-17A inhibitor, in ankylosing spondylitis. N Engl J Med 2015; 373:2534-2548. [PubMed: 26699169]

26. Dick AD, Tugal-Tutkun I, Foster S, et al. Secukinumab in the treatment of noninfectious uveitis: results of three randomized, controlled clinical trials. Ophthalmology 2013; 120:777-787. [PubMed: 23290985]

27. Letko E, Yeh S, Foster CS, et al. Efficacy and safety of intravenous secukinumab in noninfectious uveitis requiring steroid-sparing immunosuppressive therapy. Ophthalmology 2015; 122:939-948. [PubMed: 25638011]

28. Farahnik B, Beroukhim K, Zhu TH, et al. Ixekizumab for the treatment of psoriasis: a review of phase III trials. Dermatol Ther (Heidelb) 2016; 6:25-37. [PubMed: 26910853]

29. van der Heijde D, Gladman DD, Kishimoto M, et al. Efficacy and safety of ixekizumab in patients with active psoriatic arthritis: 52-week results from a phase III study (SPIRIT-P1). J Rheumatol 2017 [Epub ahead of print] This article reports on the sustained efficacy of ixekizumab in the treatment of psoriatic arthritis during a Phase III study. This was a multicentre, randomized, double-blind, active and placebo-controlled study in biologic drug-naive patients. The active agent control used was adalimumab.

30. Nash P, Kirkham B, Okada M, et al. Ixekizumab for the treatment of patients with active psoriatic arthritis and an inadequate response to tumour necrosis factor inhibitors: results from the 24-week randomised, double-blind, placebo-controlled period of the SPIRIT-P2 phase 3 trial. Lancet 2017; 389:2317-2327. [PubMed: 28551073] \ This article reports on the sustained efficacy of ixekizumab in the treatment of psoriatic arthritis during a Phase III study. This was a multicentre, randomized, double-blind, placebo-controlled study in biologic drug-naive patients.

31. Blauvelt A, Papp KA, Lebwohl MG, et al. Rapid onset of action in patients with moderate-tosevere psoriasis treated with brodalumab: a pooled analysis of data from two phase 3 randomized clinical trials (AMAGINE-2 and AMAGINE-3). J Am Acad Dermatol 2017; 77:372-374. [PubMed: 28711089]

32. Papp KA, Reich K, Paul C, et al. A prospective phase III, randomized, double-blind, placebocontrolled study of brodalumab in patients with moderate-to-severe plaque psoriasis. $\mathrm{Br} \mathrm{J}$ Dermatol 2016; 175:273-286. [PubMed: 26914406]

33. Lebwohl M, Strober B, Menter A, et al. Phase 3 studies comparing brodalumab with ustekinumab in psoriasis. N Engl J Med 2015; 373: 1318-1328. [PubMed: 26422722]

34. Sun L, He C, Nair L, et al. Interleukin 12 (IL-12) family cytokines: role in immune pathogenesis and treatment of CNS autoimmune disease. Cytokine 2015; 75:249-255. [PubMed: 25796985]

35. Cua DJ, Sherlock J, Chen Y, et al. Interleukin-23 rather than interleukin-12 is the critical cytokine for autoimmune inflammation of the brain. Nature 2003; 421:744-748. [PubMed: 12610626]

36. Aggarwal S, Ghilardi N, Xie MH, et al. Interleukin-23 promotes a distinct CD4 T cell activation state characterized by the production of interleukin-17. J Biol Chem 2003; 278:1910-1914. [PubMed: 12417590]

37. Kastelein RA, Hunter CA, Cua DJ. Discovery and biology of IL-23 and IL-27: related but functionally distinct regulators of inflammation. Annu Rev Immunol 2007; 25:221-242. [PubMed: 17291186]

38. Jiang S, Liu X, Luo L, et al. Elevated serum IL-23 correlates with intraocular inflammation after cataract surgery in patients with Vogt-Koyanagi-Harada disease. Br J Ophthalmol 2010; 94:10781082. [PubMed: 19910285]

39. Yang P, Foster CS. Interleukin 21, interleukin 23, and transforming growth factor beta1 in HLAA29-associated birdshot retinochoroidopathy. Am J Ophthalmol 2013; 156:400-406; e402. [PubMed: 23622563] 
40. Przepiera-Bedzak H, Fischer K, Brzosko M. Extra-articular symptoms in constellation with selected serum cytokines and disease activity in spondyloarthritis. Mediators Inflamm 2016; 2016:7617954. [PubMed: 28053373]

41. Abu El-Asrar AM, Berghmans N, Al-Obeidan SA, et al. The cytokine interleukin-6 and the chemokines CCL20 and CXCL13 are novel biomarkers of specific endogenous uveitic entities. Invest Ophthalmol Vis Sci 2016; 57:4606-4613. [PubMed: 27603722]

42. Velez G, Roybal CN, Colgan D, et al. Precision medicine: personalized proteomics for the diagnosis and treatment of idiopathic inflammatory disease. JAMA Ophthalmol 2016; 134:444448. [PubMed: 26848019]

43. Dong H, Li Q, Zhang Y, et al. IL23R gene confers susceptibility to ankylosing spondylitis concomitant with uveitis in a Han Chinese population. PLoS One 2013; 8:e67505. [PubMed: 23840727]

44. Hou S, Kijlstra A, Yang P. Molecular genetic advances in uveitis. Prog Mol Biol Transl Sci 2015; 134:283-298. [PubMed: 26310161]

45. Kim SW, Kim ES, Moon CM, et al. Genetic polymorphisms of IL-23R and IL-17A and novel insights into their associations with inflammatory bowel disease. Gut 2011; 60:1527-1536. [PubMed: 21672939]

46. Sandborn WJ, Gasink C, Gao LL, et al. Ustekinumab induction and maintenance therapy in refractory Crohn's disease. N Engl J Med 2012; 367:1519-1528. [PubMed: 23075178]

47. Feagan BG, Sandborn WJ, Gasink C, et al. Ustekinumab as induction and maintenance therapy for Crohn's disease. N Engl J Med 2016; 375: 1946-1960. [PubMed: 27959607]

48. Leonardi CL, Kimball AB, Papp KA, et al. Efficacy and safety of ustekinumab, a human interleukin-12/23 monoclonal antibody, in patients with psoriasis: 76-week results from a randomised, double-blind, placebo-controlled trial (PHOENIX 1). Lancet 2008; 371:1665-1674. [PubMed: 18486739]

49. Papp KA, Langley RG, Lebwohl M, et al. Efficacy and safety of ustekinumab, a human interleukin-12/23 monoclonal antibody, in patients with psoriasis: 52-week results from a randomised, double-blind, placebo-controlled trial (PHOENIX 2). Lancet 2008; 371:1675-1684. [PubMed: 18486740]

50. Griffiths CE, Strober BE, van de Kerkhof P, et al. Comparison of ustekinumab and etanercept for moderate-to-severe psoriasis. N Engl J Med 2010; 362:118-128. [PubMed: 20071701]

51. McInnes IB, Sieper J, Braun J, et al. Efficacy and safety of secukinumab, a fully human antiinterleukin-17A monoclonal antibody, in patients with moderate-to-severe psoriatic arthritis: a 24-week, randomised, double-blind, placebo-controlled, phase II proof-of-concept trial. Ann Rheum Dis 2014; 73:349-356. [PubMed: 23361084]

52. Ritchlin C, Rahman P, Kavanaugh A, et al. Efficacy and safety of the anti-IL-12/23 p40 monoclonal antibody, ustekinumab, in patients with active psoriatic arthritis despite conventional nonbiological and biological antitumour necrosis factor therapy: 6-month and 1-year results of the phase 3, multicentre, double-blind, placebo-controlled, randomised PSUMMIT 2 trial. Ann Rheum Dis 2014; 73:990-999. [PubMed: 24482301]

53. Langley RG, Tsai TF, Flavin S, et al. Efficacy and safety of guselkumab in patients with psoriasis who have an inadequate response to ustekinumab: results of the randomized, double-blind, phase III NAVIGATE trial. Br J Dermatol 2018; 178:114-123. [PubMed: 28635018]

54. Reich K, Armstrong AW, Foley P, et al. Efficacy and safety of guselkumab, an antiinterleukin-23 monoclonal antibody, compared with adalimumab for the treatment of patients with moderate to severe psoriasis with randomized withdrawal and retreatment: results from the phase III, doubleblind, placebo-and active comparator-controlled VOYAGE 2 trial. J Am Acad Dermatol 2017; 76:418-431. [PubMed: 28057361]

55. Blauvelt A, Papp KA, Griffiths CE, et al. Efficacy and safety of guselkumab, an antiinterleukin-23 monoclonal antibody, compared with adalimumab for the continuous treatment of patients with moderate to severe psoriasis: results from the phase III, double-blinded, placebo- and active comparator-controlled VOYAGE 1 trial. J Am Acad Dermatol 2017; 76:405-417. [PubMed: 28057360]

Curr Opin Ophthalmol. Author manuscript; available in PMC 2020 May 05. 
56. Reich K, Papp KA, Blauvelt A, et al. Tildrakizumab versus placebo or etanercept for chronic plaque psoriasis (reSURFACE 1 and reSURFACE 2): results from two randomised controlled, phase 3 trials. Lancet 2017; 390:276-288. [PubMed: 28596043]

57. Sands BE, Chen J, Feagan BG, et al. Efficacy and safety of MEDI2070, an antibody against interleukin 23, in patients with moderate to severe Crohn's disease: a phase 2a study. Gastroenterology 2017; 153:77-86; e76. [PubMed: 28390867]

58. Papp KA, Blauvelt A, Bukhalo M, et al. Risankizumab versus ustekinumab for moderate-to-severe plaque psoriasis. N Engl J Med 2017; 376:1551-1560. [PubMed: 28423301]

59. Feagan BG, Sandborn WJ, D'Haens G, et al. Induction therapy with the selective interleukin-23 inhibitor risankizumab in patients with moderate-tosevere Crohn's disease: a randomised, doubleblind, placebo-controlled phase 2 study. Lancet 2017; 389:1699-1709. [PubMed: 28411872]

60. Lin P Targeting interleukin-6 for noninfectious uveitis. Clin Ophthalmol 2015; 9:1697-1702. [PubMed: 26392750]

61. Tanaka T, Narazaki M, Kishimoto T. IL-6 in inflammation, immunity, and disease. Cold Spring Harb Perspect Biol 2014; 6:a016295. [PubMed: 25190079]

62. Babon JJ, Varghese LN, Nicola NA. Inhibition of IL-6 family cytokines by SOCS3. Semin Immunol 2014; 26:13-19. [PubMed: 24418198]

63. Eulenfeld R, Dittrich A, Khouri C, et al. Interleukin-6 signalling: more than Jaks and STATs. Eur J Cell Biol 2012; 91:486-495. [PubMed: 22138086]

64. Yoshimura T, Sonoda KH, Ohguro N, et al. Involvement of Th17 cells and the effect of anti-IL-6 therapy in autoimmune uveitis. Rheumatology (Oxford) 2009; 48:347-354. [PubMed: 19164426]

65. Tode J, Richert E, Koinzer S, et al. Intravitreal injection of anti-interleukin (IL)-6 antibody attenuates experimental autoimmune uveitis in mice. Cytokine 2017; 96:8-15. [PubMed: 28267649] This study in mice found that local blockade of IL-6 can reduce the severity of uveitis, illustrating the critical role of IL-6 in the pathogenesis of ocular inflammation.

66. Chen W, Zhao B, Jiang R, et al. Cytokine expression profile in aqueous humor and sera of patients with acute anterior uveitis. Curr Mol Med 2015; 15:543-549. [PubMed: 26238370]

67. de Visser L,H de Boer J,T Rijkers G, et al. Cytokines and chemokines involved in acute retinal necrosis. Invest Ophthalmol Vis Sci 2017; 58:2139-2151. [PubMed: 28395298] ■ This study looked at cytokine aqueous and serum levels from 19 patients with acute retinal necrosis and compared them to both infectious uveitis controls and normal controls.

68. Mansour AM, Arevalo JF, Ziemssen F, et al. Long-term visual outcomes of intravitreal bevacizumab in inflammatory ocular neovascularization. Am J Ophthalmol 2009; 148:310-316; e312. [PubMed: 19427992]

69. Weiss K, Steinbrugger I, Weger M, et al. Intravitreal VEGF levels in uveitis patients and treatment of uveitic macular oedema with intravitreal bevacizumab. Eye (Lond) 2009; 23:1812-1818. [PubMed: 19169227]

70. Valentincic NV, de Groot-Mijnes JD, Kraut A, et al. Intraocular and serum cytokine profiles in patients with intermediate uveitis. Mol Vis 2011; 17:2003-2010. [PubMed: 21850175]

71. Jones G The AMBITION trial: tocilizumab monotherapy for rheumatoid arthritis. Expert Rev Clin Immunol 2010; 6:189-195. [PubMed: 20402381]

72. Yokota S, Tanaka T, Kishimoto T. Efficacy, safety and tolerability of tocilizumab in patients with systemic juvenile idiopathic arthritis. Ther Adv Musculoskelet Dis 2012; 4:387-397. [PubMed: 23227116]

73. Sepah YJ, Sadiq MA, Chu DS, et al. Primary (month-6) outcomes of the STOP-Uveitis study: evaluating the safety, tolerability, and efficacy of tocilizumab in patients with noninfectious uveitis. Am J Ophthalmol 2017; 183:71-80. [PubMed: 28887113] $\mathbf{0}$ This article reports initial results on the use of tocilizumab for noninfectous uveitis. This is a randomized, open-label multicentre clinical trial evaluating safety, efficiacy and bioactivity.

74. Papo M, Bielefeld P, Vallet H, et al. Tocilizumab in severe and refractory noninfectious uveitis. Clin Exp Rheumatol 2014; 32:S75-S79. [PubMed: 25268663]

75. Mesquida M, Molins B, Llorenc V, et al. Targeting interleukin-6 in autoimmune uveitis. Autoimmun Rev 2017; 16:1079-1089. [PubMed: 28778705] 
76. Boyapati A, Msihid J, Fiore S, et al. Sarilumab plus methotrexate suppresses circulating biomarkers of bone resorption and synovial damage in patients with rheumatoid arthritis and inadequate response to methotrexate: a biomarker study of MOBILITY. Arthritis Res Ther 2016; 18:225. [PubMed: 27716324]

77. Strand V, Kosinski M, Chen CI, et al. Sarilumab plus methotrexate improves patient-reported outcomes in patients with active rheumatoid arthritis and inadequate responses to methotrexate: results of a phase III trial. Arthritis Res Ther 2016; 18:198. [PubMed: 27600829]

78. Deisseroth A, Ko CW, Nie L, et al. FDA approval: siltuximab for the treatment of patients with multicentric Castleman disease. Clin Cancer Res 2015; 21:950-954. [PubMed: 25601959]

79. Mease PJ, Gottlieb AB, Berman A, et al. The efficacy and safety of clazakizumab, an antiinterleukin-6 monoclonal antibody, in a phase IIb study of adults with active psoriatic arthritis. Arthritis Rheumatol 2016; 68: 2163-2173. [PubMed: 27059799]

80. Horiuchi T, Mitoma H, Harashima S, et al. Transmembrane TNF-alpha: structure, function and interaction with anti-TNF agents. Rheumatology (Oxford) 2010; 49:1215-1228. [PubMed: 20194223]

81. Dick AD, Duncan L, Hale G, et al. Neutralizing TNF-alpha activity modulates T-cell phenotype and function in experimental autoimmune uveoretinitis. J Autoimmun 1998; 11:255-264. [PubMed: 9693974]

82. Raveney BJ, Copland DA, Dick AD, Nicholson LB. TNFR1-dependent regulation of myeloid cell function in experimental autoimmune uveoretinitis. J Immunol 2009; 183:2321-2329. [PubMed: 19635911]

83. Hernández Garfella ML, Palomares Fort P, Román Ivorra JA, Cervera Taulet E. Aqueous humor levels of different interleukins $1-\beta, 2,6$ and 10, tumor necrosis factor-a and vascular endothelial growth factor in uveitis treated with adalimumab. J Ophthalmic Vis Res 2015; 10:49-54. [PubMed: 26005553]

84. Levy-Clarke G, Jabs DA, Read RW, et al. Expert panel recommendations for the use of antitumor necrosis factor biologic agents in patients with ocular inflammatory disorders. Ophthalmology 2014; 121:785-796; e783. [PubMed: 24359625]

85. Jaffe GJ, Dick AD, Brézin AP, et al. Adalimumab in patients with active noninfectious uveitis. N Engl J Med 2016; 375:932-943. [PubMed: 27602665]

86. Nguyen QD, Merrill PT, Jaffe GJ, et al. Adalimumab for prevention of uveitic flare in patients with inactive noninfectious uveitis controlled by corticosteroids (VISUAL II): a multicentre, doublemasked, randomised, placebo-controlled phase 3 trial. Lancet 2016; 388:1183-1192. [PubMed: 27542302]

87. Cordero-Coma M, Calvo-Río V, Adán A, et al. Golimumab as rescue therapy for refractory immune-mediated uveitis: a three-center experience. Mediators Inflamm 2014; 2014:717598. [PubMed: 24976689]

88. Yazgan S, Celik U, Işık M, et al. Efficacy of golimumab on recurrent uveitis in HLA- B27-positive ankylosing spondylitis. Int Ophthalmol 2017; 37:139-145. [PubMed: 27154720] प This small retrospective study on the use of golilumab in HLA-B27 patients with refractory anterior uveitis demonstrates effective treatment and remission of uveitis in the majority of patients over a median follow-up time of 11 months.

89. Calvo-Río V, Blanco R, Santos-Gómez M, et al. Golimumab in refractory uveitis related to spondyloarthritis. Multicenter study of 15 patients. Semin Arthritis Rheum 2016; 46:95-101. [PubMed: 27060872]

90. Cordero-Coma M, Sobrin L. Antitumor necrosis factor-a therapy in uveitis. Surv Ophthalmol 2015; 60:575-589. [PubMed: 26164735]

91. Gaujoux-Viala C, Giampietro C, Gaujoux T, et al. Scleritis: a paradoxical effect of etanercept? Etanercept-associated inflammatory eye disease. J Rheumatol 2012; 39:233-239. [PubMed: 22174213]

92. Saurenmann RK, Levin AV, Feldman BM, et al. Risk of new-onset uveitis in patients with juvenile idiopathic arthritis treated with anti-TNFalpha agents. J Pediatr 2006; 149:833-836. [PubMed: 17137902] 
93. Sabat R, Ouyang W, Wolk K. Therapeutic opportunities of the IL-22-IL-22R1 system. Nat Rev Drug Discov 2014; 13:21-38. [PubMed: 24378801]

94. Sonnenberg GF, Fouser LA, Artis D. Border patrol: regulation of immunity, inflammation and tissue homeostasis at barrier surfaces by IL-22. Nat Immunol 2011; 12:383-390. [PubMed: 21502992]

95. Witte E, Witte K, Warszawska K, et al. Interleukin-22: a cytokine produced by T, NK and NKT cell subsets, with importance in the innate immune defense and tissue protection. Cytokine Growth Factor Rev 2010; 21:365-379. [PubMed: 20870448]

96. Plank MW, Kaiko GE, Maltby S, et al. Th22 cells form a distinct Th lineage from Th17 cells in vitro with unique transcriptional properties and Tbet-dependent Th1 plasticity. J Immunol 2017; 198:2182-2190. [PubMed: 28100680] 1 An animal study showing that Th22 cells are a distinct lineage from Th17 cells, and that their differentiation is positively regulated by ROR $\gamma \tau$ and negatively regulated by Tbet. Depending on the environment to which they are exposed, Th22 cells can develop plasticity towards a Th1 or Th2 phenotype.

97. Lejeune D, Dumoutier L, Constantinescu S, et al. Interleukin-22 (IL-22) activates the JAK/STAT, ERK, JNK, and p38 MAP kinase pathways in a rat hepatoma cell line. Pathways that are shared with and distinct from IL-10. J Biol Chem 2002; 277:33676-33682. [PubMed: 12087100]

98. Ke Y, Sun D, Jiang G, et al. IL-22-induced regulatory CD11b+ APCs suppress experimental autoimmune uveitis. J Immunol 2011; 187: 2130-2139. [PubMed: 21795593]

99. Caspi RR, Mattapallil MJ, Rigden R, et al. Neuroprotective effects of IL-22 during CNS inflammation (CCR4P.203). J Immunol 2015; 194.

100. Sugita S, Kawazoe Y, Imai A, et al. Role of IL-22- and TNF-alpha-producing Th22 cells in uveitis patients with Behcet's disease. J Immunol 2013; 190:5799-5808. [PubMed: 23630362]

101. Kim Y, Kim TW, Park YS, et al. The role of interleukin-22 and its receptor in the development and pathogenesis of experimental autoimmune uveitis. PLoS One 2016; 11:e0154904. [PubMed: 27166675]

102. Sainz-de-la-Maza M, Molins B, Mesquida M, et al. Interleukin-22 serum levels are elevated in active scleritis. Acta Ophthalmol 2016; 94:e395-e399. [PubMed: 27009382]

103. Cordero-Coma M, Calleja S, Llorente M, et al. Serum cytokine profile in adalimumab-treated refractory uveitis patients: decreased IL-22 correlates with clinical responses. Ocul Immunol Inflamm 2013; 21: 212-219. [PubMed: 23617852]

104. Li Z, Liu B, Maminishkis A, et al. Gene expression profiling in autoimmune noninfectious uveitis disease. J Immunol 2008; 181:5147-5157. [PubMed: 18802119]

105. Ouyang W, Rutz S, Crellin NK, et al. Regulation and functions of the IL-10 family of cytokines in inflammation and disease. Annu Rev Immunol 2011; 29:71-109. [PubMed: 21166540]

106. Fiorentino DF, Bond MW, Mosmann TR. Two types of mouse T helper cell. IV. Th2 clones secrete a factor that inhibits cytokine production by Th1 clones. J Exp Med 1989; 170:20812095. [PubMed: 2531194]

107. Bettini M, Vignali DA. Regulatory T cells and inhibitory cytokines in autoimmunity. Curr Opin Immunol 2009; 21:612-618. [PubMed: 19854631]

108. Verma R, Balakrishnan L, Sharma K, et al. A network map of Interleukin-10 signaling pathway. J Cell Commun Signal 2016; 10:61-67. [PubMed: 26253919]

109. Donnelly RP, Dickensheets H, Finbloom DS. The interleukin-10 signal transduction pathway and regulation of gene expression in mononuclear phagocytes. J Interferon Cytokine Res 1999; 19:563-573. [PubMed: 10433356]

110. Rizzo LV, Xu H, Chan CC, et al. IL-10 has a protective role in experimental autoimmune uveoretinitis. Int Immunol 1998; 10:807-814. [PubMed: 9678762]

111. Rosenbaum JT, Angell E. Paradoxical effects of IL-10 in endotoxin-induced uveitis. J Immunol 1995; 155:4090-4094. [PubMed: 7561121]

112. Broderick CA, Smith AJ, Balaggan KS, et al. Local administration of an adeno-associated viral vector expressing IL-10 reduces monocyte infiltration and subsequent photoreceptor damage during experimental autoimmune uveitis. Mol Ther 2005; 12:369-373. [PubMed: 16043105]

113. Rizzo LV, Morawetz RA, Miller-Rivero NE, et al. IL-4 and IL-10 are both required for the induction of oral tolerance. J Immunol 1999; 162: 2613-2622. [PubMed: 10072503] 
114. Agarwal RK, Horai R, Viley AM, et al. Abrogation of antiretinal autoimmunity in IL-10 transgenic mice due to reduced $\mathrm{T}$ cell priming and inhibition of disease effector mechanisms. $\mathrm{J}$ Immunol 2008; 180:5423-5429. [PubMed: 18390724]

115. Takase H, Futagami Y, Yoshida T, et al. Cytokine profile in aqueous humor and sera of patients with infectious or noninfectious uveitis. Invest Ophthalmol Vis Sci 2006; 47:1557-1561. [PubMed: 16565392]

116. Sauer A, Villard O, Creuzot-Garcher C, et al. Intraocular levels of interleukin 17A (IL-17A) and IL-10 as respective determinant markers of toxoplasmosis and viral uveitis. Clin Vaccine Immunol 2015; 22:72-78. [PubMed: 25378353]

117. Pochat-Cotilloux C, Bienvenu J, Nguyen AM, et al. Use of a threshold of interleukin-10 and IL-10/IL-6 ratio in ocular samples for the screening of vitreoretinal lymphoma. Retina 2017 [Epub ahead of print] A study of 119 patients looking at IL-10/IL-6 ratios in vitreous and aqueous humour for the diagnosis of vitreoretinal lymphoma. A ratio of more than 1 was associated with a diagnosis of vitreoretinal lymphoma.

118. Kuo DE, Wei MM, Armbrust KR, et al. Gradient boosted decision tree classification of endophthalmitis versus uveitis and lymphoma from aqueous and vitreous IL-6 and IL-10 levels. J Ocul Pharmacol Ther 2017; 33: 319-324. [PubMed: 28157416] @ This small study shows that gradient boosting, a machine learning predictive model, can differentiate endophthalmitis from uveitis and lymphoma using vitreous IL-6 and IL-10 with fairly high accuracy, sensitivity and specificity.

119. Whitcup SM, Stark-Vancs V, Wittes RE, et al. Association of interleukin 10 in the vitreous and cerebrospinal fluid and primary central nervous system lymphoma. Arch Ophthalmol 1997; 115:1157-1160. [PubMed: 9298057]

120. Chan CC, Whitcup SM, Solomon D, Nussenblatt RB. Interleukin-10 in the vitreous of patients with primary intraocular lymphoma. Am J Ophthalmol 1995; 120:671-673. [PubMed: 7485372]

121. Fedorak RN, Gangl A, Elson CO, et al. Recombinant human interleukin 10 in the treatment of patients with mild to moderately active Crohn's disease. The Interleukin 10 Inflammatory Bowel Disease Cooperative Study Group. Gastroenterology 2000; 119:1473-1482. [PubMed: 11113068]

122. Schreiber S, Fedorak RN, Nielsen OH, et al. Safety and efficacy of recombinant human interleukin 10 in chronic active Crohn's disease. Crohn's Disease IL-10 Cooperative Study Group. Gastroenterology 2000; 119: 1461-1472. [PubMed: 11113067]

123. Colombel JF, Rutgeerts P, Malchow H, et al. Interleukin 10 (Tenovil) in the prevention of postoperative recurrence of Crohn's disease. Gut 2001; 49:42-46. [PubMed: 11413109]

124. Marlow GJ, van Gent D, Ferguson LR. Why interleukin-10 supplementation does not work in Crohn's disease patients. World J Gastroenterol 2013; 19:3931-3941. [PubMed: 23840137] 


\section{KEY POINTS}

- Th17 cells and their related cytokines are important mediators of inflammation in autoimmune diseases including uveitis.

- The anti-TNFa therapy, adalimumab, is currently the only FDA-approved biologic treatment for uveitis.

- Due to their role in the development of the pathologic Th17 fate, IL-6 and IL-23 are attractive potential therapeutic targets in ocular inflammatory disease.

- The anti-IL-6 therapy, tocilizumab and the anti-IL-23 therapy ustekinumab are actively being investigated in clinical trials for their efficacy and safety in the treatment of uveitis. 